\title{
Empirical Evidence of the Moderating Effect of Effective Audit Committee on Audit Experience in the Public Sector: Perception of Internal Auditors
}

\author{
Mu'azu Saidu Badara \\ Siti Zabedah Saidin \\ School of Accountancy, Universiti Utara Malaysia \\ muazubadara@yahoo.com
}

Doi:10.5901/mjss.2014.v5n10p176

\begin{abstract}
Researches that focus on the moderating effect of effective audit committee within the public sector setting are very scanty or no attention has been given at all. Therefore, the objective of this study is to empirically examine the moderating effective of effective audit committee on the relationship between audit experience and internal audit effectiveness in the public sector using the perception of internal auditors. Data of the study were collected through research assistant employed, in which 300 questionnaire were sent to internal auditors in the North West geo-political zone local government in Nigeria. The study used simple random sampling technique; data were analyzed using Statistical Package for Social Science (SPSS) version 21. Descriptive statistic, factor analysis, correlation matrix and finally, hierarchical multiple regression analysis were carried out. The result findings of the analysis revealed that, audit experience has a significant positive relationship with internal audit effectiveness and effective audit committee were significantly moderates such relationship. Finally, conclusion was provided and the direction for future research was also provided.
\end{abstract}

Keywords: Effective audit committee, audit experience, internal audit effectiveness, public sector.

\section{Introduction}

Internal auditors within the public sector are very significant tools that demand full consideration due to the effective role play in organizational survival, because they review the activities of organizational operation with aim of ensuring their compliance with relevant organizational policies and standard and thereby making good recommendation for their improvement. Nevertheless, within the past few decades, researches that focus on the explanation of the current functions of the internal audit within the world are very scanty (Sarens \& Abdolmohammadi, 2011; Endaya \& Hanefah, 2013). The fact that it's very important to have an effective and efficient function of internal audit within an organization (Kinsella, 2010) because internal audit functions that is well perform, serve as an effective means for monitoring and promoting system of good governance in any organization (Belay, 2007; Kangarlouei, Motavasse, \& Mohammadzadeh 2013). But then, such internal audit are still found not effective within the public sector organization (Salawu and Agbeja, 2007; Emmanuel, Ajanya, \& Audu, 2013). Even Endaya and Hanefah (2013) acknowledged that, only few studies conducted on such internal audit effectiveness within the world. That is why they finally recommend more research to be conducted on internal audit effectiveness.

Audit experience has become one of the factor to be consider when it comes to internal audit effectiveness issues, because it enable the achievement of good quality auditing and thereby leads to the provision of good recommendation. In fact, experience auditor has the ability of identifying the right information that will aid his judgment (Bonner, 1990). In line with this, audit experience has been suggested as one of the auditing research area (Sudsomboon \& Ussahawanitchakit, 2009). Therefore, future research are required to conduct research on such audit experience (Ussahawanitchakit, 2012), even Badara and Saidin (2013) emphasized for the validation of such relationship empirically. Therefore, it's important to empirically conduct research on the implication of audit experience on such audit effectiveness.

One of the essential aspects for ascertaining the effectiveness of internal audit; is the nature of reporting structure which required reporting to the audit committee directly (Krishnamoorthy, 2008; Marshall, 2013; Montondon, 1995; Owolabi \& Dada, 2011). Audit committees are encouraged to perform essential functions so that internal auditor meets the required professional standard of independence, integrity, and objectivity (Sharma, Sharma, \& Ananthanarayanan, 2011). Audit committee are required to support their internal audit departments by way of ensuring conformity with IIA 
standards; setting clear performance expectations; making sure all essentials resources are supplied to the department of internal audit so that to effectively discharge their responsibilities. Hence, internal audit functions that have full support of audit committee are probable to be of highly objective and thereby enable good objective achievement of the internal auditors (Endaya \& Hanefah, 2013; MatZain \& Subramaniam, 2004; Nolan \& Smith, 2008).

Most of the research that has been conducted on effective audit committee give their concerned at private sector, such as their implication with regard to financial statement or audit fees (Alkdai \& Hanefah, 2012; Bukit \& Iskandar, 2009; Bu-Peow Ng \& Tan, 2003; Chelimo \& Kariuki, 2013; Domnisoru \& Vinatoru, 2008; Mat Zain, Subramania, \& Stewart, 2006). Even the limited study that focus on such moderating effect of effective audit committee give concentration to such moderating effect on earnings management (Bukit \& Iskandar, 2009; Kamarudin et al, 2012; Krishnamoorthy 2008; Sharma et al, 2011). Thereby ignoring to study the moderating effect of such audit committee within the context of public sector, while concerned has been given that future research should pay maximum consideration on the operation of audit committee in the organizational and institutional contexts and its interaction with other internal structures of an entity, in fact it should be primary subject of future research (Akarak \& Ussahawanitchakit, 2010; Mat Zain, et al, 2006; Turley \& Zaman, 2004; Turley \& Zaman 2007). Also Turley and Zaman (2004) emphasize on the limited research on the effect of audit committee on internal control system, internal audit and risk management. However, it's important to empirically examine the moderating effects of effective audit committee (Sharma et al, 2011).

In view of the above issues, the objective of this study is to empirically examine the moderating effect of effective audit committee on the relationship between audit experience and internal audit effectiveness in the public sector via the perception of internal auditors. Section two of the paper presents the literature review and hypothesis development, section three provides research methodology, section four present the results and discussion and finally the conclusion.

\section{Literature Review and Hypothesis Development}

\subsection{Internal audit effectiveness}

As indicated above that only limited studies conducted on internal audit effectiveness, take for instance among the recent one (Ahmad, Othman, \& Jusoff, 2009; Arena \& Azzone, 2009; Bota \& Palfi, 2009; Arena \& Azzone, 2010; Cohen \& Sayag, 2010; Mihret, James \& Joseph, 2010; Theofanis, Drogalas \& Giovanis, 2011; Unegbu \& Kida 2011; Feizizadeh, 2012; Badara \& Saidin, 2012; Badara \& Saidin, 2013; Endaya \& Hanefah, 2013). For example; Ahmad et al, (2009) conducted an empirical studies on the effectiveness of internal audit in Malaysian public sector using few sample size that attained symposium in Malaysia. The study revealed that, shortage of audit staff is categorized as the major problem faced by internal auditors in conducting an effective internal auditing and at the end they recommends more research on internal audit effectiveness. Cohen and Sayag (2010) equally conducted an empirical study on the effectiveness of internal auditing in Israeli organizations. The study employed the following variables in examining the internal audit effectiveness; sector - private versus public, professional proficiency of internal auditors, quality of audit work, organizational independence, career and advancement and finally top management support. The study revealed that, support of management is almost crucial to the operation and success of internal audit. And other determinants of internal audit effectiveness derive from support of top management. The study recommends more research to be conducted on internal audit effectiveness.

Unegbu and Kida (2011) carried out an empirical study on the effectiveness of internal audit as instrument of improving public sector management in Nigeria within the Kano state public sector organization, and finally the study showed that, internal audit can effectively check fraud and fraudulent activities in the public sector and that public sectors in Kano state have significant numbers of internal audit departments to function effectively. Likewise, Feizizadeh (2012) conducted a literature review conceptual paper on the strengthening of internal audit effectiveness in Iran and finally the study concluded that most of the companies measure and quantify the performance \& effectiveness of their business activities. In addition, Endaya and Hanefah (2013) conducted another conceptual study on internal audit effectiveness: An approach proposition to develop the theoretical framework. The study concluded that sufficient theories should be used toward supporting the internal audit effectiveness (the study utilized three theories, agency, institutional and communication theories). Finally, the study observed that only limited studies been conducted on internal audit effectiveness all over the world and thereby stressed the need for more future studies on such internal audit effectiveness. 


\subsection{Audit experience}

Research in audit experience has been given due consideration for a longer period of time (Wright \& Wright, 1997). Even in the recent period, such research on audit experience keep receiving researchers concerned (Gaballa \& Ning 2011; Wang, Yu, Zhang \& Zhao, 2012; Badara \& Saidin, 2013). This shows the important of audit experience, due to the fact that auditors that have well experience enable the provision of good quality audit findings and thereby enable good recommendations. This is in line with Knapp and Knapp (2001) which observed that, various researches on experience and expertise recommend that, an individual's knowledge changes as experience broaden. Libby and Frederick (1990) equally suggested that, this knowledge advantage was as a result of the ability to generate more likely explanations for audit findings. And this led the earlier researchers on audit experience suggested that, when an auditors gain experience, it is an indication that; they know more about errors; they have more accurate knowledge on error; they know more occasional errors, and the causes of errors (Gaballa \& Ning, 2011; Libby \& Frederick, 1990; Cohen \& Kida, 1989; Intakhan \& Ussahawanitchakit, 2010).

As auditors gain experience, their knowledge structures become well developed (Arel, Kaplan \& Donnell, 2005; Libby \& Frederick, 1990; Bonner, 1990). That is why even the public sector organizations are required to recruit more experience auditors (Ebimobowei \& Binaebi, 2013). Auditors that have well experience are usually engage in different assignment and decision making (Libby \& Frederick, 1990). This indicates that audit experience is an important factor to be considered by public sector organization in determining the effectiveness of their internal audit effectiveness.

Previous studies that has been conducted on audit experience focused on the effect of such experience on error discovery in the financial statement (e.g. Messier, 1983; Cohen \& Kida 1989; Bonner, 1990; Libby \& Frederick, 1990; Choo \& Trotman, 1991; Shelton, 1999; Chung \& Monroe, 2000), while for the recent one that has been conducted include (Asare et al, 2009; Intakhan \& Ussahawanitchakit 2010; Gaballa \& Ning, 2011; Wang et al, 2012; Badara \& Saidin, 2013). Thereby did not empirically investigate the effect of such experience on the effectiveness of internal auditors predominantly within the public sector setting. Badara and Saidin (2013) have emphasized for the empirical validation of such relationship in different countries. Therefore, this study extends the previous studies by empirically examining such relationship within the public sector setting using the perceptions of the internal auditors.

Several research has postulate that audit experience can have impact on the of internal audit issues (Al-Twaijry, Brierley \& Gwilliam, 2003; Bonner, 1990; Chung \& Monroe, 2000; Chi, Myers, Omer \& Xie, 2010; Intakhan \& Ussahawanitchakit, 2010; Modlin, 2012; Ussahawanitchakit, 2012; Wang et al, 2012; Wright \& Wright, 1997). For example; auditors with more experience have a good comprehension of decision process and placed greater reliance on the net income variable (Messier, 1983). Likewise, earnings quality of both public and private companies is increasing in auditor experience (Chi et al., 2010). In addition, Al-Twaijry et al., (2003) also noted some of the factors that influence internal audit effectiveness include; experience, training, education and professional qualifications. Libby and Frederick (1990) found that experience auditors have the ability to give more explanations of audit findings. Therefore, in view of the above theoretical presumptions, the following hypothesis is developed;

H1: Audit experience is significantly related to internal audit effectiveness in the public sector organization.

\subsection{Effective audit committee}

More researchers concerned are increasing recently on audit committee as one of the component of corporate governance (Chen, Duh \& Shiue, 2008; Davies, 2009; Barua, Rama \& Sharma, 2010; Alkdai \& Hanefah, 2012), because audit committee especially is they are effective, plays important role in reducing corporate inefficiency (Owolabi \& Dada, 2011). Even though is been argued that such audit committee are unsuccessful in the protection of corporate failures as well as corporate irregularities (Ogbada, Orok \& Esang, 2009). Nevertheless, consideration must be given toward encouraging their effectiveness so that to enable corporate effectiveness and thereby enhance the effectiveness of internal auditors, because such committee can be seen as a body that can be used to bring changes in an organization setting (Owolabi \& Dada, 2011). Audit committee is effective when they meet the goals for which they were established which include the improvement of the entity's overall governance (David, 2009; Haron, Chambers, Ramsi \& Ismail, 2005).

Due to relevance of audit committee generally, several countries have promulgate the establishment of audit committee in their various private and public sectors in order to ensure effectiveness of activities (Al-Mudhaki \& Joshi, 2004; Turley \& Zaman, 2004). Even Institute of Internal Auditors in their effort on improving the effectiveness of internal auditor, release a statement title the audit committee in the public sector in 1991 which stipulate that, all public sector entity should have an establish audit committee that will ensure the effectiveness of internal auditors (Montondon, 1995). The effectiveness of such committee needs to be evaluated from time to time by various public sector organizations 
(Quigley 2012). In this vein, many governments established audit committee in order to strengthen their internal audit and external audit functions, financial management, financial reporting, internal controls system and overall governance (David, 2009). Hence, internal audit functions which have full concentration of audit committee are probable to be of greater objective and thereby enable good objective achievement of the internal auditors (Endaya \& Hanefah, 2013; MatZain \& Subramaniam, 2004; Nolan \& Smith, 2008).

Most of the previous studies that has been conducted on such audit committee concentrated on the impact of such audit committee on audit fees and error discovery in financial statement in the private sectors such as companies (e.g. Bu-Peow Ng \& Tan, 2003; Mat Zain, et al, 2006; Domnisoru \& Vinatoru, 2008; Sarens, De Beelde \& Everaert, 2009; Akarak \& Ussahawanitchakit; 2010; Alkdai \& Hanefah, 2012; Chelimo \& Kariuki, 2013). Even the one that focus on the moderating effect of such audit committee concentrated on the moderating effect of such committee on management earnings (e.g. Krishnamoorthy 2008; Bukit \& Iskandar, 2009; Sharma et al, 2011; Kamarudin et al, 2012). Thereby given limited or no attention to the moderating effect of such committee in the public sector setting predominantly on internal audit effectiveness, while concerned has been given that future research should pay maximum consideration on the operation of audit committee in the organizational and institutional contexts and its interaction with other internal structures of an entity, in fact it should be primary subject of future research (Akarak \& Ussahawanitchakit, 2010; Mat Zain, et al, 2006; Turley \& Zaman, 2004; Turley \& Zaman 2007). Also Turley and Zaman (2004) emphasize on the limited research on the effect of audit committee on internal control system, internal audit, and risk management. However, it's important to empirically examine the moderating effects of effective audit committee (Sharma et al, 2011).

Therefore, in view of the above issue, this study extends the previous studies through investigating the moderating effective of effective audit committee on the relationship between audit experience and internal audit effectiveness in the public sector using the perception of internal auditors. In this vein, literature made presumption that needs validation empirically particularly, that effective audit committee may strength the audit experience toward achieving better internal audit. For examples; Davies (2009) posited that audit committee should strength both head of internal audit and internal audit function in achieving a high level independence and objectivity, qualification and experience. Similarly, audit committee should continue monitor and ensure that internal auditors have required skills that might improve their respective roles and responsibilities (Nolan \& Smith, 2008). Hence, internal audit functions which have full concentration of audit committee are probable to be of greater objective and thereby enable good objective achievement of the internal auditors (Endaya \& Hanefah, 2013; MatZain \& Subramaniam, 2004; Nolan \& Smith, 2008). Therefore, in view of the above issues, the following hypothesis is formulated.

H2: Effective audit committee seems to moderate the relationship between audit experience and internal audit effectiveness in the public sector organizations.

\subsection{Contingency theory}

Contingency theory of Woodward (1958) is been employed as the underpinning theory for the research due to the fact that, the theory is one of those theory that are recently been employed in the research area of management accounting and auditing (Valanciene \& Gimzauskiene, 2009; Abushaiba \& Zainuddin, 2012). Even though, the use of theory may have different effect, and equally it effectiveness depend upon the field that is been proposed (Drazin \& Van de Ven, 1985). Nevertheless, contingency theory enables a researcher to systematically introduce factors to explain or predict expected phenomena (Umanath, 2003). The theory enable hypothesize a conditional relationship between two or more independent variables with a dependent variable and subject it to an empirical validation (Drazin \& Van de Ven, 1985).

The theory also contributes in the identification of relationship that is complex among variables i.e. examining moderating or mediating effect of variables (Heo \& Han, 2003). This is in line with Sekaran and Bougie (2009) which affirmed that moderating variables is the one which has strong contingent effect on the relationship between independent and dependent variables. Equally, the theory has been employed by previous researchers in explaining some of the research variables (Krishnamoorthy, 2008), even with regard to audit effectiveness the theory has equally employed by previous researchers (Sudsomboon and Ussahawanitchakit, 2009) as contingent variables can also differ (wood, 2009). Therefore, this study theorized that internal audit effectiveness in the public sector organization is contingent upon the contingency variables of; audit experience and the moderating effect of effective audit committee on such relationship.

\section{Research Methodology}

The data for this study were obtained through a survey questionnaire administered to the internal auditors within the North West geo-political zones in Nigeria. The population of the study is the entire local government in the North West 
geo-political zones in Nigeria. There are 186 local government in the North West geo-political zones in Nigeria, based on this population, the sample size is 127 (Watson, 2001). To reduce the sample error in order to take care with nonresponse problem, the sample size has been increase to 300 (Hair, Black, Babin \& Anderson, 2010). It is also recommended that the larger the sample size, the better (Pallant, 2001). The sampling technique was simple random sampling, in which every element in the population has equal chance of been selected as a sample, it has least bias and offer the most generalizability (Sekaran \& Bougie, 2009). The data were administered and collected through research assistant employed so that to facilitate quick retrieval of completed research questionnaire and equally to provide high responds rate. Therefore, out of 300 questionnaires distributed, 230 were fully completed and returned which represent $77 \%$ responds rate. A response rate of $30 \%$ is acceptable for survey (Hair et al, 2010).

\subsection{Measurement of research variables}

\subsubsection{Dependent variable}

Internal audit effectiveness: Internal audit effectiveness is the ability of the internal auditors to achieved established objective of the internal audit function. This variable is the dependent variable; the variable is measured by 9 items adapted with some modification (Beckmerhagen, Berg, Karapetrovic, \& Willborn, 2004).

Audit experience: is the independent variable and it refers to different kind of knowledge and skills which the auditor obtains as a result in length of tenure on the job practice in the auditing professions which enhance his effectiveness. Therefore, this variable is measured with 5 items as adapted with some modification (Mihret \& Woldeyohannis, 2008).

Effective audit committee: is the moderating variable and it refers to the ability of the audit committee to achieve established objective as well as strengthen the audit experience toward the achievement of internal audit effectiveness. Therefore, this variable is measured with 6 items as adapted with some modification (Davies, 2009; Kamarudin et al 2012; Sarens et al, 2009).

Thus, five -point type rating scale, ranging from strongly agree to strongly disagree has been used in measuring the responses of the entire questions. This is because several researchers has make used of this scale due to its easier for respondents to understand, hence, responses from five point scale are probably to be reliable (Chelimo \& Kariuki, 2013; Theofanis, et al, 2011; Zuriekat, Salameh \& Alrawashdeh, 2011). Face and content validity of the instrument was carried out through meeting with the expert on the field in order to ensure that those items that contain in the instrument actually belong to that particular instrument. The expert contacted consisted of Academic staff in Nigerian Institutions, Auditor General for Local Government in Nigeria, internal auditors at state and local government in Nigeria, so that to improve the validity of the instrument. To this end, after taking note on the expert observation, a revised version of the instrument was made which result to some questions were re- worded in order to measure the constructs appropriately, so that to enable clear understanding by the potential respondents, which thereafter administered for pilot study. The reliability of the pilot study was all above 0.7 which indicate the reliability of the measurement (Hair, et. al, 2010).

\subsection{Method of data analysis}

The data were analyzed using SPSS version 21, hence descriptive statistic was carried out, factor analysis was equally carried out so that to reduce the items into more manageable number (Pallant, 2001). After the factor analysis, the items remain for each variable certified the requirement of factor analysis, such as KMO $>0.5$, Bartlett's test of Sphericity $p<$ 0.05 or smaller, communalities $>0.5$, factor loading above $>0.5$ (Hair et al., 2010), as you can see the factor loadings and the cronbach alpha of the variables in Table 2. Correlation matrix has been carried out and lastly, hierarchical multiple regression analysis was then conducted.

\section{Result and Discussions}

\subsection{Descriptive statistic}

Table 1.0 present the background information of the respondents, the result revealed that $74.8 \%$ of the respondents are male while $25.2 \%$ of the respondents are female; this implies that the male respondents outweigh the female respondents. Descriptive statistic result indicated that $27.4 \%$ of the respondents are within the age of $30-35$ years old which implies that the majority of respondents are within the productive age of the entire population which their responses 
can equally be fair. With regard to highest school qualification, the result shows that majority of the respondents are within diploma/ NCE certificates which represent $47.4 \%$. Majority of the respondents have no professional certificate as revealed by descriptive statistic result with $78.7 \%$. Finally, the result equally displayed that majority of the respondents have enough working experience as showed in table 1.0 which represent $32.2 \%$

Table 1.0: Background information of the respondents

\begin{tabular}{llcc}
\hline Demographic profile & Categories & Frequency & $\%$ \\
\hline \multirow{3}{*}{ Gender: } & Male & 172 & 74.8 \\
& Female & 58 & 25.2 \\
& Total & 230 & 100.0 \\
\hline \multirow{4}{*}{ Age: } & Less than 25 years old & 6 & 2.6 \\
& 25 years - 30 years old & 43 & 18.7 \\
& 30 years - 35 years old & 63 & 27.4 \\
& 35 years - 40 years old & 53 & 23.0 \\
& 40 years - 45 years old & 43 & 18.7 \\
& Above 45 years old & 22 & 9.6 \\
& Total & 230 & 100.0 \\
\hline Highest school qualification & Secondary certificate & 9 & 3.9 \\
& Certificate & 19 & 8.3 \\
& Diploma/NCE & 109 & 47.4 \\
& Degree/HND & 79 & 34.3 \\
& Masters & 14 & 6.1 \\
& Total & 230 & 100.0 \\
\hline \multirow{5}{*}{ Wrofessional qualification } & ICAN member & 4 & 1.7 \\
& ANAN member & 30 & 13.0 \\
& ICPAN member & 14 & 6.1 \\
& None & 181 & 78.7 \\
& Others specify & 1 & .5 \\
& Total & 230 & 100.0 \\
\hline & Less than 1 year & 3 & 1.3 \\
& $1-5$ years & 50 & 21.7 \\
& 6-10 years & 58 & 25.2 \\
& 11-15 years & 45 & 19.6 \\
& 15 years - Above & 32.2 \\
& Total & 100.0 \\
\hline & & &
\end{tabular}

Table 2: Results of Measure Validation

\begin{tabular}{lcc}
\hline Items & Factor Loadings & Cronbach Alpha \\
\hline Internal Audit Effectiveness (IAE) & $0.64-0.79$ & 0.79 \\
Audit Experience (AE) & $0.87-0.95$ & 0.80 \\
Effective Audit Committee (EAC) & $0.60-0.80$ & 0.71 \\
\hline
\end{tabular}

Table 2 above provided the results for both factor loadings and Cronbach alpha, it can be seen from the Table that the factor loading of the variables range from $0.60-0.95$, hence, it is an indication of construct validity (Hair et al., 2010). The cronbach alpha value indicates the constructs reliability because the value range from $0.71-0.80$. Hence is indicating that scales of all measures appear to produce internally consistent results (Hair et al., 2010).

Table 3: Correlation Matrix

\begin{tabular}{lccc}
\hline & IAE & AE & EAC \\
\hline Internal Audit Effectiveness (IAE) & 1 & & \\
Audit Experience (AE) & $.343^{\star *}$ & 1 & \\
Effective Audit Committee (EAC) & $.281^{* *}$ & $.318^{\star *}$ & 1 \\
\hline
\end{tabular}

**. Correlation is significant at the 0.01 level (2-tailed).

*. Correlation is significant at the 0.05 level (2-tailed). 
The correlation analysis of the variables under study was subjected to a two- tailed test of statistical significance at two different level; significant $(p<0.01)$ and significant $(p<0.05)$. Table 3 above shows that correlations between all variables under study are statistically significant at $(p<0.01)$ respectively. It can also be seen from the same table 3 that the correlation of the variables ranges from 0.281 to 0.343 . Hence, the problem of multicollinearity is not there.

Table 4: Hierarchical regression result of the moderating effect of effective audit committee on the relationship between audit experience and internal audit effectiveness

\begin{tabular}{lccc}
\hline Independent Variable & \multicolumn{3}{c}{ Dependent Variable: IAE } \\
& Step 1 & Step 2 & Step 3 \\
\hline Audit experience (AE) & .247 & .222 & .223 \\
& $(.002)$ & $(.004)$ & $(.003)$ \\
Interactive Terms: & & & \\
Moderating Variable: & & .254 & .138 \\
Effective Audit Committee (EAC) & & $(.000)$ & $(.000)$ \\
& & & -.157 \\
Effective Audit Committee x Audit experience & & $(.000)$ \\
& & & .321 \\
R2 & .262 & $* 369$ \\
Significant P< & $* * 0.01$ & $* 0.05$ & $* 0.1$ \\
\hline
\end{tabular}

Table 4 above displayed the result of regression analysis of the relationship between audit experience and internal audit effectiveness and the moderating effect of effective audit committee. Audit experience has significant positive relationship with internal audit effectiveness ( $\beta=.247, t=3.100, p=.002$ ). This implies that, the more the experience of the internal auditor the greater his effectiveness will be. In other word, those internal auditors that have auditing experience can easily find it easier to achieve their respective objective. This finding is in line with the findings of Anuntaakalakul (2010) who found that internal auditors that have more experience have a higher success level in consultant and governance roles than the less experience one. At the same time, in order to achieve effective audit outcomes, audit experience is the main driver \& determiner because it has influence on audit effectiveness (Intakhan \& Ussahawanitchakit 2010). Hence, H1 is supported

Equally, Table 4 above revealed the significant of moderating effect of effective audit committee on the relationship between audit experience and internal audit effectiveness $(\beta=-.157, t=-4.378, p=.000)$. This finding entails that, organization that have experience auditors would also need a strong support of effective audit committee that would assist toward the effectiveness of internal auditors. This is in line with prior studies, for example Alberta (2005) suggested that audit committees are required to support their internal audit departments by way of ensuring conformity with IIA standards; setting clear performance expectations; making sure that the department has all the necessary resources to meet their responsibilities. Equally, the finding of Arena and Azzone's (2009), Endaya and Hanefah (2013) revealed that, present of an effective audit committee in organization strength the effectiveness of internal auditors. Thus, H2 is supported.

\section{Conclusions}

This study provided the empirical evidence of the moderating effect of effective audit committee on the relationship between audit experience and internal audit effectiveness in the public sector using the perception of internal auditors. The result analysis of the study revealed the significant effect of audit experience on the internal audit effectiveness and the moderating effect of effective audit committee on such relationship, which implies that, for public sector organization to attain the effectiveness of their internal audit, such audit experience and effective audit committee need to be given due consideration. Some of the limitation of the study includes; collecting data from local government only even though is part of the public sector setting, the research was based on cross-sectional and the finding cannot be generalized due to different setting of various public sector organization internal audits in different countries.

Despite the above limitations, the study contributed to internal audit effectiveness by providing empirical evidence of audit experience and effective audit committee on internal audit effectiveness, which previous studies has not empirically investigated in examining the internal audit effectiveness. Therefore, more research are require to be conducted on internal audit effectiveness particularly in the public sector setting because literature has showed limited study and reporting of internal audit within the context of various public sector setting. Future studies should incorporate different significant theories in explaining the effectiveness of internal audit. 


\section{References}

Abushaiba, I. A, \& Zainuddin, Y. (2012). Performance measurement system design, competitive capability, and performance consequences - A conceptual like. International Journal of Business and Social Science, 3(11), 184-193.

Ahmad, N., Othman, R, \& Jusoff, K. (2009). The effectiveness of internal audit in Malaysian public sector. Journal of Modern Accounting and Auditing, 5(9), 784 - 790.

Akarak, P, \& Ussahawanitchakit, P. (2010). Audit committee effectiveness and firm credibility: An empirical investigation of Thai-Listed firms. International Journal of Business research, 10(2), 38-63.

Alberta, A. G. (2005). Examination of internal audit departments. Internal Audit Report. Retrieve on 12/09/2012 from http://www.oag.ab.ca/files/oag/Examination_IAD.pdf

Alkdai, H. K .H, \& Hanefah, M. M. (2012). Audit committee characteristics and earnings management in Malaysian Shariah-compliant companies. Business and Management Review, 2(2), $52-61$.

Al-Mudhaki, J, \& Joshi, P. L. (2004). The role and functions of audit committees in the Indian corporate governance: Empirical findings. International Journal of Auditing, 8, 33- 47

Al-Twaijry, A. A. M, Brierley, J. A, \& Gwilliam, D. R. (2003). The development of internal audit in Saudi Arabia: An Institutional Theory perspective. Critical Perspective on Accounting, 14, 507-531. doi:10.1016/S1045-2354(02)00158- 2.

Anuntaakalakul, A. (2010). The achievement in risk management and governance of public sector organizations in Thailand: The Empirical Evidence of Internal Auditing efforts. EABR \& ETLC Conference Proceedings Dublin, Ireland, 99-104.

Arel, B., Kaplan, S. E, \& Donnell, E. O. (2005). Evaluating internal controls: The moderating effect of auditor experience on the persuasiveness of evidence from management self-assessment, 1- 33.

Arena, M, \& Azzone. G. (2009). Identifying organizational drivers of internal audit. effectiveness. International Journal of Auditing, 13, 43-60.

Arena, M, \& Azzone. G. (2010). Internal audit effectiveness: Relevant drivers of auditees satisfaction1-35.

Badara, M. S \& Saidin, S. Z. (2012). Impact of the effective internal control system on the internal audit effectiveness at local government level. Journal of Social and Development Sciences. 4(1), 16-23.

Badara, M. S \& Saidin, S. Z. (2013). The relationship between audit experience and internal audit effectiveness in the public sector organizations. International. Journal of Academic Research in Accounting, Finance and Management Sciences. 3(3), 329-339.

Barua, A., Rama, D.V, \& Sharma, V. (2010). Audit committee characteristics and investment in internal auditing. J. Account. Public Policy, 29, 503-513. doi:10.1016/j.jaccpubpol.2010.09.001.

Beckmerhagen, I. A., Berg, H. P., Karapetrovic, \& Willborn, W. O. (2004). On the effectiveness of quality management system audits. The TQM Magazine, 16(1), 14-25.

Belay, Z. (2007). A Study on effective implementation of internal audit function to promote good governance in the public sector. Presented to the "The Achievements, Challenges, and Prospects of the Civil Service Reform program implementation in Ethiopia" Conference Ethiopian Civil Service College Research, Publication \& Consultancy Coordination Office.

Bonner, S. E. (1990). Experience effects in auditing: The role of task-specific knowledge. The Accounting Review, 65(1), 72-92.

Bota, C, \& Palfi, C. (2009). Measuring and assessment of internal audit's effectiveness. Economic Science Series, 18(3), 784-790.

Bukit, R, \& Iskandar, T. M. (2009). Surplus free cash flow, earnings management and audit committee. Int. Journal of Economics and Management, 3(1), 204 - 223.

Bu-Peow Ng, T \& Tan, H. (2003). Effects of authoritative guidance availability and audit committee effectiveness on auditors' judgments in an auditor-client negotiation context. The Accounting Review, 78(3), 801-818.

Chenhall, R. H. (2003). Management control systems design within its organizational context: Findings from contingency-based research and directions for the future. Accounting Organizations and Society, 28, 127-168.

Cohen, A, \& Sayag, G. (2010). The Effectiveness of internal auditing: An empirical examination of its determinants in Israeli organizations. Australian Accounting Review, 54 (20), 296-307. Doi: 10.1111/j.1835- 2561.2010.00092.x.

Cohen, J, \& Kida, T. (1989). The impact of analytical review results, internal control reliability and experience on auditors' use of analytical review. Journal of Accounting Research, 27(2), $263-276$

Chi, W., Myers, L.A., Omer, T. C, \& Xie, H. (2010). The effects of auditors' pre- client and client-specific experience on earnings quality and perceptions of earnings quality: Evidence from private and public companies in Taiwan. 1- 38.

Chelimo, A. K., \& Kariuki, B. M. (2013). An evaluation of internal audit committee functions in financial reporting in local authorities in Kenya: A case municipal council of Eldoret. Journal of Emerging Trends in Economics and Management Sciences (JETEMS), 4(2) 289-295

Chen, J., Duh, R, \& Shiue, F. N. (2008). The effect of audit committees on earnings- return Association: Evidence from foreign registrants in the United States. Corporate Governance, 16(1), 32- 40. Doi:10.1111/j.1467- 8683.2008.00660.x.

Choo, F, \& Trotman, K. T. (1991). The Relationship between knowledge structure and judgments for experienced and inexperienced auditors. The accounting review, 66(3), 464-485

Chung, J, \& Monroe, G. S. (2000). The effects of experience and task difficulty on accuracy and confidence assessments of auditors. Accounting and Finance 40, 135-152.

David, I. T. (2009). Characteristics of Effective Audit Committees in Federal, State and Local Governments. Journal of Government Financial Management. 45 - 48.

Davies, M. (2009). Effective working relationships between audit committees and internal audit, the cornerstone of corporate governance in local authorities, a Welsh perspective. J Manage Gov, 13, 41-73. doi 10.1007/s10997-008-9070- 9.

Domnisoru, S, \& Vinatoru, S. S. (2008). Auditor independence, audit committee quality and internal control weaknesses. Annals of the University of Petrosani, Ecoomics, 8(1), 161-166.

Drazin, R, \& Van de Ven, A. H. (1985). Alternative forms of fit in contingency Theory. Administrative Science Quarterly, 30, 514-539.

Ebimobowei, A, \& Binaebi, B. (2013). An Examination of the effectiveness of auditing of local government financial reports in Bayelsa State, Nigeria. Current Research Journal of Social Sciences 5(2) 45-53.

Emmanuel, O. E., Ajanya, M. A., \& Audu, F. (2013). An assessment of internal control Audit on the efficiency of Public sector in Kogi State Nigeria. Mediterranean Journal of Social Sciences, 4(11), 717 - 726.

Endaya, K. E., \& Hanefah, M. M. (2013). Internal audit effectiveness: An approach proposition to develop the theoretical framework. Research Journal of Finance and Accounting, 4(10), 92 -102

Feizizadeh, A. (2012). Strengthening internal audit effectiveness. Indian Journal of Science and Technology, 5(5), 2777- 2778.

Gaballa, A. S. M, \& Ning, Z. (2011). An analytical study of the effects of experience on the performance of the external auditor. International Conference on Business and Economics Research, 1, $169-173$.

Hair, J., Black, W. C., Babin, B. J, \& Anderson, R. E. (2010). Multivariate danalysis (7 $7^{\text {th }}$ Edition). Uppersaddle River, New Jersey: Pearson Education International.

Haron, H., Chambers, A., Ramsi, R., \& Ismail. I. (2004). The reliance of external auditors on internal auditors. Managerial Auditing Journal, 19 (9), 1148- 
1159. DOI 10.1108/02686900410562795.

Heo, J, \& Han, I. (2003). Performance measure of information systems (IS) in evolving computing environments: an empirical investigation. Information \& Management, 40, 243-256.

Intakhan, P, \& Ussahawanitchakit, P. (2010). Roles of audit experience and ethical reasoning in audit professionalism and audit effectiveness through a moderator of stakeholder pressure: An empirical study of tax auditors in Thailand. Journal of Academy of Business and Economics, 10(5), 1-15.

Kamarudin, K. A., Ismail, W. A. W, \& Samsuddin, M. E. (2012). The role of the audit committee in moderating the negative effect of non-audit services on earnings quality. 1-17. Electronic copy available at: http://ssrn.com/abstract=2051258.

Kangarlouei, S, J., Motavasse, M., \& Mohammadzadeh, V. (2013). Evaluation of internal audit effectiveness in Tehran Stock Exchange (TSE). International Journal of Advances in Management and Economics, 2(1), 77-82.

Kinsella, D. (2010). Assessing your internal audit function. Accountancy Ireland, 42(2), 10-12.

Knapp, C. A, \& Knapp, M. C. (2001). The effects of experience and explicit fraud risk assessment in detecting fraud with analytical procedures. Accounting, Organizations and Society, 26, 25-37.

Krishnamoorthy, G. (2008). The role of internal audit in the financial statement audit: The contingent effects of Board independence and audit committee effectiveness. 1-29.

Libby, R, \& Frederick, D. M. (1990). Experience and the ability to explain audit findings. Journal of Accounting Research, 28(2), 348 - 367.

Marshall, R. (2013). Effective internal audit in the financial services sector, recommendations from the committee on internal audit guidance for financial services. Institute of Internal Audit. 1-16.

Mat Zain, M, \& Subramaniam, N. (2004). Audit committee characteristics, internal auditors' contribution to financial statement audits and audit fees: Malaysian evidence. presentation at the Fourth Asia Pacific Interdisciplinary Research in Accounting Conference, Singapore.

Mat Zain, M., Subramania, N, \& Stewart, J. (2006). Internal Auditors' assessment of their contribution to financial statement audits: The relation with audit committee and internal audit Function characteristics. International Journal of Auditing, 10, 1-18.

Messier, W. F. (1983). The effect of experience and firm type on materiality/disclosure judgments. Journal of Accounting Research, (2), $611-618$.

Mihret, D. G., James, K, \& Joseph, M. M. (2010). Antecedents and organizational performance implications of internal audit effectiveness: some propositions and research agenda. Pacific Accounting Review, 22(3), 224 - 252.

Mihret, D. G, \& Woldeyohannis, G. Z. (2008). Value-added role of internal audit: An Ethiopian case study. Managerial Auditing Journal, 23(6), 567 - 595.

Modlin, S. (2012). County government finance practices: What independent auditors are finding and what makes local government susceptible. Journal of Public Budgeting, Accounting \& Financial Management, 24 (4), 558-578.

Montondon, L. (1995). Accountability in Municipalities: The use of internal auditors and audit committee. The American Review of Public Administration, 25, 59- 69. Doi: $10.1177 / 027507409502500104$

Nolan, M. J., \& Smith, E. R. (2008). Audit committee roundup finding new value in internal audit. 73 -74.

Owolabi, S. A, \& Dada, S. O. (2011). Audit committee: An instrument of effective corporate governance. European Journal of Economics, Finance and Administrative Sciences, 35, 173-183.

Ogbada, E.I., Orok. E, \& Esang, A. E. (2009). The challenges of Nigerian economy under her present day audit committees.1-24. Electronic copy available at: http://ssrn.com/abstract=1444255.

Pallant, J. (2001). SPSS survival manual. A step by step guide to data analysis using SPSS for windows (Version 10) (1st Edition). Allen \& Unwin Australia.

Quigley, S. (2012). Audit committees and public sector accountability. Public sector accountancy Ireland, 44(1), 36-37.

Salawu, R. S, \& Agbeja, O. (2007). Auditing and accountability in the public sector. International Journal of Applied Economics and Finance, 1 (1), 45 - 54.

Sarens, G, \& Abdolmohammadi, M. J. (2011). Monitoring effects of the internal audit function: Agency Theory versus other Explanatory Variables. International Journal of Auditing, 15, 1-20.

Sarens, G., De Beelde, I, \& Everaert, P. (2009).Internal audit: A comfort provider to the audit committee. The British Accounting Review 41, 90-106. Doi:10.1016/j.bar.2009.02.002.

Sekaran, U, \& Bougie, R (2009). Research method for business; A skill building approach. Fifth edition. A john Wiley and sons, Ltd. United Kingdom.

Sudsomboon, S, \& Ussahawanitchakit, P. (2009). Professional audit competencies: the effects On Thai's CPAS audit quality, reputation, and success. Review of Business Research, 9(3), $66-85$.

Sharma, V. D., Sharma, D. S, \& Ananthanarayanan, U. (2011). Client importance and earnings management: The moderating role of audit committees. Auditing: A Journal of Practice \& Theory American Accounting Association, 30(3), 125- 156. DOI: 10.2308/ajpt-10111.

Shelton, S. W. (1999). The effect of experience on the use of irrelevant evidence in auditor's judgment. The Accounting Review, 74(2), $217-224$.

Theofanis, K., Drogalas, G, \& Giovanis, N. (2011). Evaluation of the effectiveness of internal audit in Greek Hotel Business. International Journal of Economic Sciences and Applied Research 4 (1): 19-34.

Turley, S, \& Zaman, M. (2004). The corporate governance effects of audit committees. Journal of Management and Governance, 8, 305-332.

Turley, S, \& Zaman, M. (2007). Audit committee effectiveness: Informal processes and behavioral effects. Accounting, Auditing and Accountability Journal, 20(5), 1-30.

Umanath, N.S. (2003). The concept of contingency beyond "It depends" illustrations from IS research stream. Information \& Management, 40, 551-562.

Unegbu, A. O, \& Kida, M. I. (2011). Effectiveness of internal audit as instrument of improving public Sector management. Journal of Emerging Trends in Economics and Management Sciences (JETEMS), 2 (4), 304-309.

Ussahawanitchakit, P. (2012). Audit independence of tax auditors in Thailand: Roles of ethical orientation, professional responsibility, stakeholder pressure, and audit experience. Journal of Academy of Business and Economics, 12(1), 1- 11.

Valanciene, L, \& Gimzauskiene, E. (2009).Dimensions of performance measurement system in changes research. Engineering Economics (4), $41-48$.

Wang, Y., Yu, L., Zhang, Z, \& Zhao, Y. (2012). Engaging audit partner experience and audit quality, 1-48.

Watson, J. (2001). How to Determine a Sample Size: Tipsheet 60, University Park, PA: Penn State Cooperative Extension. Retrieved on 21/10/2012 from http://www.extension.psu.edu/evaluation/pdf/TS60.pdf

Wright, A, \& Wright, S. (1997). The effect of industry experience on hypothesis generation and audit planning decisions. Retrieve on $1 / 08$ /2012 from Social Science Research Network Electronic Paper Collection: http://papers.ssrn.com/paper.taf?abstract_id=42913

Woods, M. (2009). A contingency theory perspective on the risk management control system within Birmingham City Council. Management Accounting Research, 20, 69-81.

Woodward, J. (1958). Contingency School of Management. Retrieved on 14/09/2012 from http://vectorstudy.com/management_schools /contingency_school.htm.

Zuriekat, M., Salameh, R, \& Alrawashdeh, S. (2011). Participation in performance measurement systems and level of satisfaction. International Journal of Business and Social Science, 2(8), $159-169$. 